\title{
Effects of genistein on the periovulatory expression of messenger ribonucleic acid for matrix metalloproteinases and tissue inhibitors of metalloproteinases in the rat ovary
}

\author{
C. M. Komar ${ }^{1}$, M. Matousek ${ }^{2}$, K. Mitsube², M. Mikuni², \\ M. Brännström ${ }^{2}$ and T. E. Curry, Jr ${ }^{1}$ \\ ${ }^{1}$ Department of Obstetrics and Gynecology, Chandler Medical Center, University of \\ Kentucky, 800 Rose Street, Room MS 331, Lexington, KY 40536-0298, USA; and \\ ${ }^{2}$ Department of Obstetrics and Gynecology, Göteborg University, Sahlgrenska University \\ Hospital, S-413 45 Göteborg, Sweden
}

The matrix metalloproteinases (MMPs) play critical roles in the ovulatory process. Their expression and activity, together with those of the endogenous tissue inhibitors of metalloproteinases (TIMPs), are stimulated by LH. The LH surge initiates a cascade of events resulting in ovulation and formation of the corpus luteum via activation of protein kinases $\mathrm{A}$ and $\mathrm{C}$, as well as tyrosine kinases. In vitro perfused rat ovaries were untreated, or treated with LH $\left(0.2 \mu \mathrm{g} \mathrm{ml}^{-1}\right)$ plus $0.2 \mathrm{mmol}$ 3-isobutyl-1-methylxanthine $\mathrm{I}^{-1}$ with 0,10 or $100 \mu \mathrm{mol}$ genistein $\mathrm{I}^{-1}$ (an inhibitor of tyrosine kinases) to assess whether tyrosine kinases are mediators of the LH-stimulated increase in ovarian expression of the MMPs and TIMPs. After $10 \mathrm{~h}$ of perfusion, ovaries were collected and frozen until RNA isolation. Northern and RNase protection analyses were used to

\section{Introduction}

Ovulation requires degradation of the apical follicle wall and dissolution of the granulosa and epithelial cell basement membranes. Matrix metalloproteinases (MMPs), a family of proteinases comprising the gelatinases, collagenases, stromelysins, and membrane-type MMPs (MT-MMPs; for review, see Matrisian, 1990; Nagase and Woessner, 1999), are capable of breaking down basement membranes and the extracellular matrix. Various members of this family are regulated by the preovulatory gonadotrophin surge and have been shown to play a critical role in the process of ovulation (Fukumoto et al., 1981; Reich et al., 1985; Murdoch et al., 1986; Yoshimura et al., 1987; Balbín et al., 1996; Hulboy et al., 1997). Administration of hCG to eCG-primed rats increases the activity of ovarian proteoglycanase, gelatinase (Curry et al., 1992) and collagenase (Curry et al., 1985; Hirsch et al., 1993), and treatment with hCG increases collagenase

Email: ckomar@uky.edu measure mRNA encoding collagenase 3 , gelatinases $A$ and $B$, and TIMPs-1, -2 and -3 . Treatment with LH plus 3isobutyl-1-methylxanthine resulted in a two- and fivefold increase in mRNA encoding collagenase 3 and TIMP-1, respectively $(P<0.05)$. Treatment with $100 \mu \mathrm{mol}$ genistein $\mathrm{I}^{-1}$ blocked the LH-stimulated increase in collagenase $3(0.012 \pm 0.002$ versus $0.028 \pm 0.005$ relative units for $100 \mu \mathrm{mol}$ genistein $\mathrm{I}^{-1}$ versus $\left.\mathrm{LH}_{\mathrm{H}} \boldsymbol{P}<0.05\right)$, whereas neither dose of genistein affected LH-induced TIMP-1 expression. LH alone or with genistein did not alter the expression of mRNA encoding TIMP-2 and TIMP-3, or mRNA encoding gelatinases $A$ and $B$. These data indicate that tyrosine kinases play a role in the $\mathrm{LH}$-induced tissue remodelling required for ovulation by mediating the LHstimulated expression of collagenase 3 .

activity in cultured rat follicles (Palotie et al., 1987). In ewes, collagenase activity increases after a GnRH-induced gonadotrophin surge (Murdoch et al., 1986), and gelatinase A activitiy in follicular fluid increases after hCG administration (Russell et al., 1995). Inhibition of MMP activity with exogenous chemical inhibitors blocks ovulation both in vitro (Brännström et al., 1988; Butler et al., 1991) and in vivo (Reich et al., 1985), further supporting a critical role for MMPs in the ovulatory process.

The activity of MMPs is regulated, in part, by tissue inhibitors of metalloproteinases (TIMPs). Four TIMPs (TIMP-1-4) have been identified to date and they inhibit MMP activity by forming non-covalent bonds with the MMPs in a 1:1 molar ratio. TIMPs bind to active and latent forms of MMPs: TIMP-1 associates with the latent form of gelatinase B (92 kDa gelatinase; MMP-9), while TIMP-2 and TIMP-4 complex with the latent form of gelatinase A (72 kDa gelatinase; MMP-2; Bigg et al., 1997; Hulboy et al., 1997). In addition to their role as inhibitors of MMPs, TIMP-1 and TIMP-2 act as growth factors (Hayakawa et al., 1992; Chesler et al., 1995; Nemeth et al., 1996; Yamashita et al., 1996) and are anti-angiogenic 
agents (Takigawa et al., 1990; Murphy et al., 1993; Johnson et al., 1994). TIMP-1 has also been shown to regulate steroidogenesis in cultured ovarian cells (Boujrad et al., 1995; Nothnick et al., 1997).

TIMP expression is similar to that of MMPs in that it is influenced by the preovulatory gonadotrophin surge. The amount of mRNA for TIMP-1 (Mann et al., 1993) and TIMP-like activity (Zhu and Woessner, 1991) increase in response to the $\mathrm{LH}$ surge and by treating cultured rat granulosa cells with LH (Mann et al., 1991). The expression of mRNA for TIMP-3 also increases after LH administration to cultured rat granulosa cells (Nothnick and Curry, 1996).

The dynamic cascade of events set in motion by the $\mathrm{LH}$ surge is mediated by the protein kinase $\mathrm{A}$ and protein kinase C pathways (Davis et al., 1986; Morris and Richards, 1995), as well as tyrosine kinases (TKs) (Wong and Richards, 1992; Morris and Richards, 1993). LH stimulates the expression of P450 side-chain cleavage, prostaglandin endoperoxide synthase 2 (Wong and Richards, 1992; Morris and Richards, 1993), and activation of tissue plasminogen activator (Shimamoto et al., 1998) in ovarian cells, in part, by activating TKs. In other tissues, TKs are involved in regulating the expression of mRNA for collagenase 1, stromelysin 1 (Li and Zafarullah, 1998), and TIMP-3 (Su et al., 1998), as well as activating gelatinase A (Li et al., 1997). However, the role of TKs in mediating MMP and TIMP activity in the ovary is unknown. The present study used genistein, an inhibitor of TKs, to test the hypothesis that TKs mediate the LH-stimulated changes in ovarian expression of gelatinases $\mathrm{A}$ and $\mathrm{B}$, collagenase 3 , and TIMPs 1-3.

\section{Materials and Methods}

\section{In vitro ovarian perfusion}

Immature female Sprague-Dawley rats (B\&K Universal, Sollentuna) were housed under controlled conditions with lights on from 05:00 to 19:00 h with ad libitum access to food and water. At 28 days of age, the rats were administered 20 iu eCG (Sigma Chemical Co., St Louis, MO) s.c. at 09:00 h. Forty-eight hours after eCG, rats were anaesthetized with a combination of ketamine (Park Davis, Barcelona; $40 \mathrm{mg} \mathrm{kg}^{-1}$ ) and xylazine (Bayer, Leverkusen; $6.5 \mathrm{mg} \mathrm{kg}^{-1}$ ); and then heparin sulphate (Lovens Ballerup; $300 \mathrm{iu})$ was injected i.v. Laparotomy was performed and the right ovary was isolated surgically as described by Brännström et al. (1987) and Koos et al. (1984). All experiments were approved by the animal ethics committee of Göteborg University.

Perfusions were performed in a recirculating system with $30 \mathrm{ml}$ M199 with Earle's salts (Gibco, Gaithersburg, MD) supplemented with gentamicin (Biological Industries, Kibbutz Beit Haemek; $50 \mu \mathrm{g} \mathrm{ml}^{-1}$ ), insulin (Novo, Bagsvaerd; 0.02 iu $\mathrm{ml}^{-1}$ ), $4 \%$ bovine serum albumin (Boehringer Mannheim, Mannheim), and $0.026 \mathrm{~mol}$ sodium bicarbonate $\mathrm{I}^{-1}$ as described by Koos et al. (1984), Brännström et al. (1987) and Matousek et al. (1999).
Ovaries were perfused approximately 30-60 min before the administration of the following treatments: control (no treatment; $n=4$ ), or $0.2 \mu \mathrm{g} \mathrm{LH} \mathrm{ml}{ }^{-1}$ (ovine LH NIADDKoLH-26) and $0.2 \mathrm{mmol} 3$-isobutyl-1-methylxanthine $\mathrm{I}^{-1}$ (IBMX; Sigma) with $0(n=8), 10(n=4)$ or $100 \mu \mathrm{mol}$ genistein $\mathrm{I}^{-1}(n=13$; Sigma). The perfusions were continued for $10 \mathrm{~h}$, after which time the ovaries were collected, frozen in liquid nitrogen, and stored at $-70^{\circ} \mathrm{C}$ for later isolation of RNA.

\section{RNase protection assay}

Total RNA was isolated from perfused ovaries using TRIZOL reagent (Gibco BRL, Rockville, MD) and quantified by spectrophotometry. RNase protection assays were used to measure mRNA for collagenase because its expression is too low to be detected using northern blot analysis. Rat cDNAs for collagenase 3 (MMP-13; a generous gift from L. Matrisian, Vanderbilt University, Nashville, TN) and mouse ribosomal protein L32 (kindly provided by O-K. Park-Sarge, University of Kentucky, Lexington, KY) were linearized with Xhol and EcoRI, respectively. Antisense riboprobes were transcribed using Ambion's MAXISCRIPT kit (Ambion Inc., Austin, TX), [ $\left.\alpha_{-}{ }^{32} \mathrm{P}\right]$ UTP (10 $\mathrm{mCi} \mathrm{ml}^{-1}$; DuPont New England Nuclear, Boston, MA) and T7 RNA polymerase.

RNase protection assays were carried out according to Ambion's RPA II kit instructions. Samples of total RNA $(6 \mu \mathrm{g})$ were hybridized for $15-18 \mathrm{~h}$ at $50^{\circ} \mathrm{C}$ with excess radiolabelled antisense riboprobe $\left(2 \times 10^{5}\right.$ c.p.m.). Loading variation among samples was standardized by including L32 riboprobe in all hybridization reactions. Protected RNA fragments were analysed by electrophoresis through a $5 \%$ acrylamide-8 mol urea $\mathrm{I}^{-1}$ gel. Quantification of band intensity in the gels was determined from an imaging plate using a phosphor-imager (Molecular Dynamics, Sunnyvale, CA). The band intensity of mRNA for collagenase 3 was normalized to the corresponding band for L32 per sample.

\section{Northern blot analysis}

Twenty micrograms of total RNA were subjected to electrophoresis through a $1 \%$ agarose gel containing 2.2 mol formaldehyde $\mathrm{I}^{-1}$, and then transferred to a Nytran membrane (Schleicher and Schuell, Keene, NH) according to the manufacturer's instructions. ${ }^{32} \mathrm{P}$-labelled cDNA probes corresponding to mouse TIMPs 1-3 and gelatinases $A$ and $B$ were synthesized as described by Nothnick et al. (1996, 1997). After probing for the TIMPs and MMPs, membranes were hybridized with a cDNA probe for rat ribosomal 18S. Expression of mRNA for the TIMPs and MMPs was normalized to the relative expression of the $18 \mathrm{~S}$ transcript per sample.

\section{Statistical analysis}

Because of the inherent variation among animals, sample values that were greater than $3 \mathrm{SD}$ from the group 
(a)

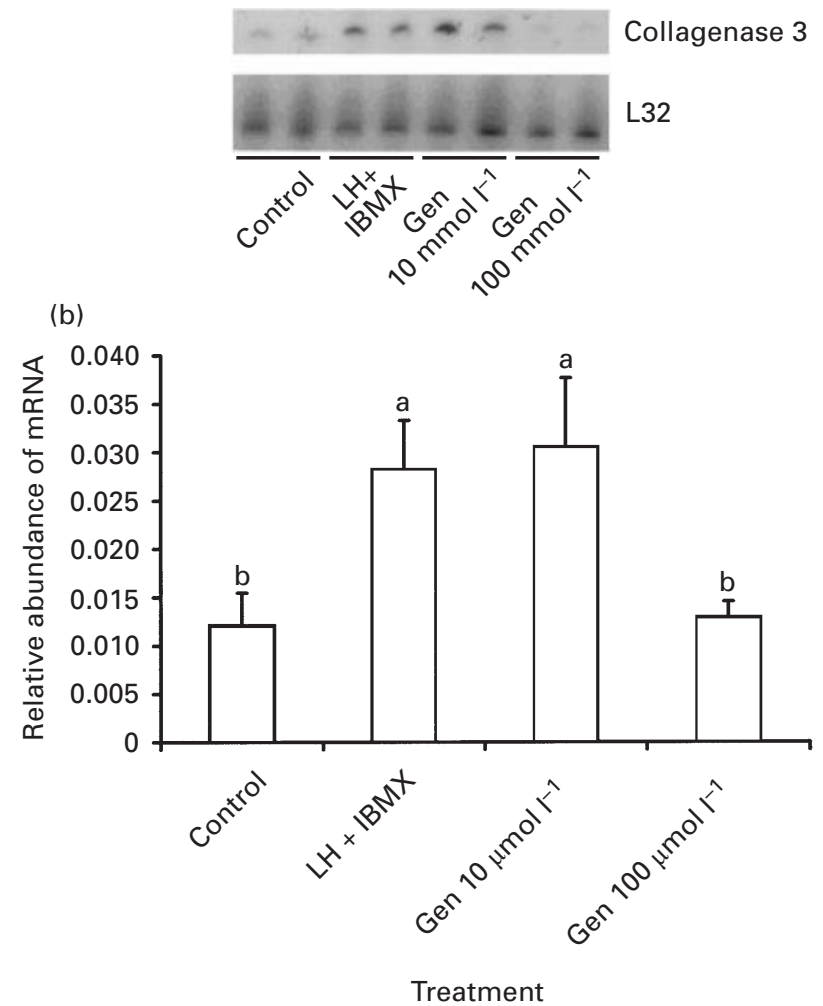

Fig. 1. (a) Representative RNase protection assay demonstrating the protected fragments of mRNA for collagenase 3 and ribosomal protein L32 in $6 \mu \mathrm{g}$ total RNA from individual in vitro perfused rat ovaries. (b) Relative abundance (mean \pm SEM) of mRNA for collagenase 3 in $6 \mu$ g total RNA isolated from in vitro perfused rat ovaries. Relative abundance as calculated by correcting for the amount of L32 within each sample. Gen: genistein; IBMX: 3isobutyl-1-methylxanthine. Bars with different superscripts are significantly different $(P<0.05)$.

mean were not included in statistical analyses. Data were subjected to Levene's test for homogeneity of variance. Log or square root transformations were performed on data that were determined to have heterogeneous variances. Effects of treatment on expression of mRNA for the MMPs and TIMPs were tested for by one-way ANOVA. Post hoc comparisons were made using Fisher's least significant difference procedure. A $P<0.05$ denoted a significant difference.

\section{Results}

The administration of $\mathrm{LH}$ to in vitro perfused rat ovaries stimulated a twofold increase in mRNA encoding collagenase $3(P<0.05$; Fig. 1$)$. Treatment with $10 \mu \mathrm{mol}$ genistein $\mathrm{I}^{-1}$ resulted in expression of mRNA for collagenase 3 that did not differ from that of $\mathrm{LH}$-treated ovaries. However, the administration of $100 \mu \mathrm{mol}$ genistein $\mathrm{I}^{-1}$ blocked the $\mathrm{LH}$-stimulated increase in expression of mRNA for collagenase $3(0.028 \pm 0.005$ versus $0.012 \pm 0.001$ relative units (a)

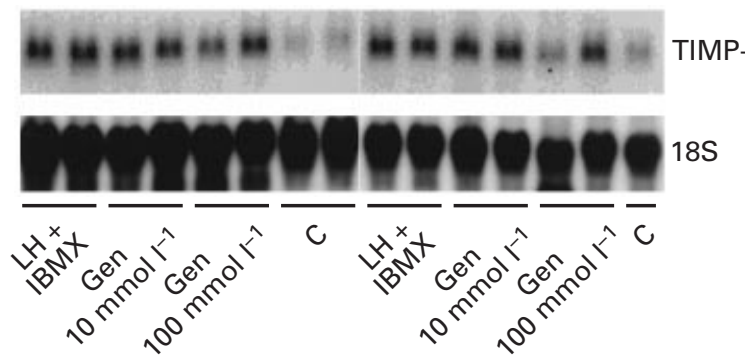

(b)

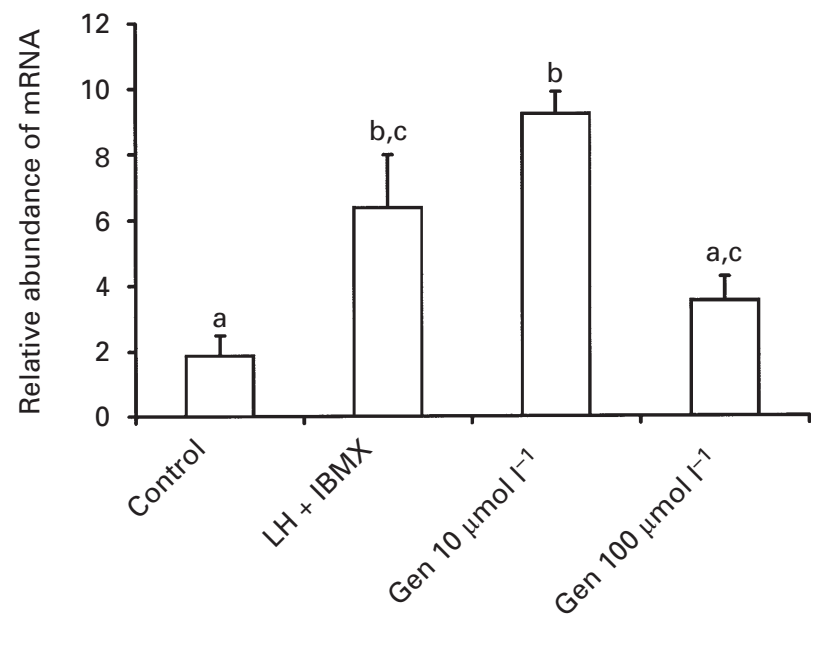

Treatment

Fig. 2. (a) Representative northern blot for tissue inhibitors of metalloproteinase 1 (TIMP-1) and ribosomal 18S mRNA in $20 \mu \mathrm{g}$ total RNA isolated from individual in vitro perfused rat ovaries. (b) Relative abundance (mean \pm SEM) of mRNA for TIMP-1 in in vitro perfused rat ovaries. Relative abundance as calculated by correcting for the amount of $18 \mathrm{~S}$ within each sample. Gen: genistein; IBMX: 3-isobutyl-1-methylxanthine. Bars with different superscripts are significantly different $(P<0.05)$.

for $\mathrm{LH}$ versus $100 \mu \mathrm{mol}$ genistein $\mathrm{I}^{-1}$ treatments, respectively; $P<0.05)$.

Treatment of in vitro perfused ovaries with $\mathrm{LH}$ resulted in a significant increase in the expression of mRNA for TIMP-1 $(1.8 \pm 0.6$ versus $6.3 \pm 1.6$ relative units for control and LH treatments, respectively; Fig. 2). There was no effect of genistein treatment on the LH-stimulated mRNA for TIMP-1, although the administration of $100 \mu \mathrm{mol}$ genistein $\mathrm{I}^{-1}$ reduced mRNA expression for TIMP-1 to a value intermediate between that from control and that from $\mathrm{LH}$-treated ovaries.

There was a trend towards an increase in mRNA for gelatinase $\mathrm{A}$ in response to $\mathrm{LH}$, although this was not significant (Fig. 3). Genistein had no effect on the expression of gelatinase A. There was no effect of treatment on the expression of mRNA for gelatinase B or TIMP-2 (data not shown). The treatment of perfused ovaries with $\mathrm{LH}$ did not 
(a)

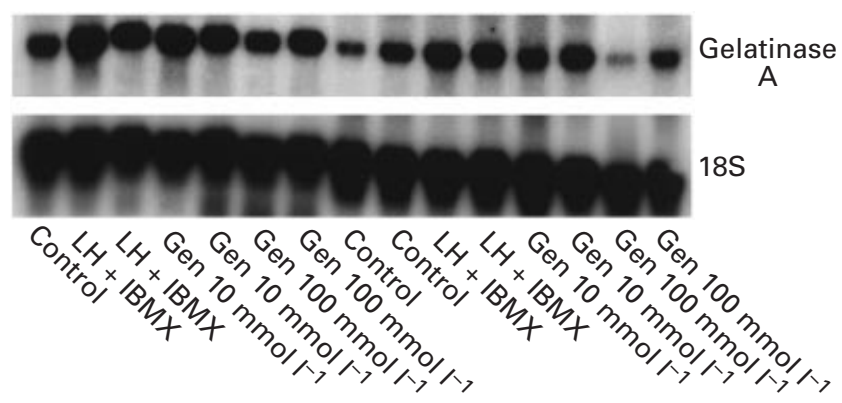

(b)

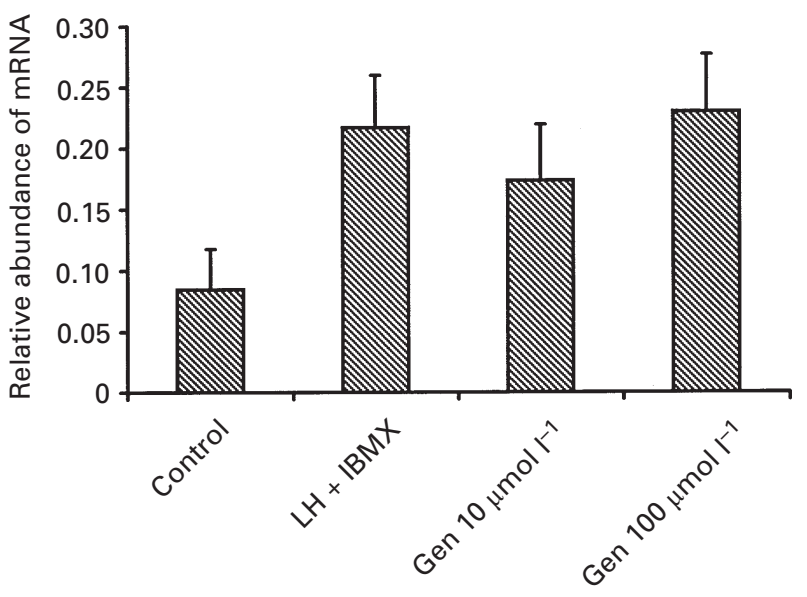

Treatment

Fig. 3. (a) Representative northern blot for gelatinase A and ribosomal $18 \mathrm{~S}$ mRNA in $20 \mu \mathrm{g}$ total RNA isolated from individual in vitro perfused rat ovaries. (b) Relative abundance (mean \pm SEM) of mRNA for gelatinase $A$ in in vitro perfused ovaries. Relative abundance as calculated by correcting for the amount of $18 \mathrm{~S}$ within each sample. Gen: genistein; IBMX: 3-isobutyl-1-methylxanthine.

alter the amount of mRNA encoding TIMP-3. The expression of mRNA encoding TIMP-3 in ovaries treated with either 10 or $100 \mu \mathrm{mol}$ genistein $\mathrm{I}^{-1}$ did not differ from that in control ovaries (data not shown).

\section{Discussion}

Treatment of in vitro perfused rat ovaries with genistein to block the activity of TKs reduces ovulation efficiency without affecting steroid production, prostaglandin production, or the activity of plasminogen activator (Matousek et al., 1999). Ovulation was also blocked when tyrophostin, another inhibitor of TKs, was administered to eCG-primed rats before the injection of hCG (Shimamoto et al., 1998). In the present study, genistein was used to assess the role of TKs in LH-stimulated changes in ovarian expression of TIMPs 1-3, collagenase 3 and the gelatinases.

The present survey of mRNA expression of MMPs critical to the ovulatory process revealed that the adminis- tration of genistein blocked the LH-stimulated increase in mRNA encoding collagenase-3. The dose of genistein that prevented the LH-induced increase in collagenase 3 also inhibited ovulation (Matousek et al., 1999). Taken together, these data can be interpreted to show that the decrease in ovulation efficiency resulting from inhibition of TKs may be due to a decrease in collagenase 3 resulting in inadequate degradation of the follicle wall.

Because genistein is a phyto-oestrogen, another mechanism by which genistein may exert its effect on the ovary is via binding to oestragen receptors. There are two types of oestradiol receptor, oestrogen receptor $\alpha$ and oestrogen receptor $\beta$, with genistein showing greater binding affinity for oestrogen receptor $\beta$ (Kuiper et al., 1997). In the ovary, oestrogen receptor $\beta$ is present in granulosa cells of developing and mature follicles (Kuiper et al., 1996; Byers et al., 1997). Both the oestrogen receptor $\beta$ mRNA (Byers et al., 1997) and protein (Fitzpatrick et al., 1999) are reduced markedly in response to the $\mathrm{LH}$ surge. Therefore, it is unlikely that the decrease in LH-stimulated mRNA for collagenase 3 seen after genistein treatment in the present study resulted from genistein binding to oestrogen receptor $\beta$ in granulosa cells.

Tyrosine kinases play a role in the expression of COX-2 (Wong and Richards, 1992; Morris and Richards, 1993), and genistein is capable of inhibiting the expression and activity of COX-2 (Akarasereenont et al., 1994; Mutoh et al., 2000). However, the reduction in ovulation efficiency (Matousek et al., 1999) and decrease in LH-stimulated collagenase 3 mRNA expression (present study) in response to genistein treatment most likely do not result from a decrease in prostaglandin production. Findings in support of this conclusion come from a study showing that the dose of genistein that inhibited ovulation did not effect prostaglandin production (Matousek et al., 1999), and Espey et al., (1991) have reported that ovulation can occur uncompromised even when prostaglandin synthesis is reduced by $80-90 \%$. These data indicate that, by blocking TK action, ovulation is affected by some mechanism other than the inhibition of prostaglandin production.

In the present study, it was suprising that the expression of mRNA for gelatinase $\mathrm{A}$ did not increase in response to LH treatment since other studies have reported an increase in both mRNA (Reich et al., 1991; Curry et al., 2000) and activity (Curry et al., 1992) during the periovulatory period. This finding may be explained by the fact that, although LH plus IBMX stimulated a 2.5-fold increase in the expression of mRNA encoding gelatinase $A$, fewer oocytes are released in the in vitro perfused ovary model than in the eCG/hCG model. This decrease in the number of ruptured follicles may result in a corresponding diminution of gelatinase A mRNA expression.

LH/hCG-induced expression of collagenase 3 has been observed using RNase protection assays (Curry et al., 2000; present study). These observations contrast with those of other investigators who were unable to identify collagenase 3 in ovaries from eCG-primed rats up to $72 \mathrm{~h}$ 
after administration of hCG (Balbín et al., 1996), or in follicles from adult cyclic rats (Liu et al., 1999). These differences in the expression of mRNA for collagenase 3 most likely reflect the greater sensitivity of the RNase protection assay compared with the northern analysis used in the other studies.

From the present study, it appears that TKs do not play a major role in LH-mediated TIMP expression during the periovulatory period. The lack of an effect of genistein on the LH-stimulated expression of mRNA for TIMP-1 indicates that this species of mRNA is regulated primarily by a second messenger system that does not depend on activation of TKs. These findings are in agreement with the presence of a cAMP response element in the upstream promoter region of the TIMP-1 gene (Edwards et al., 1992; O-K. Park-Sarge, personal communication). TIMP-2 tends to be constitutively expressed and its expression does not appear to change in response to the $\mathrm{LH}$ surge (Inderdeo et al., 1996; Nothnick et al., 1997; Smith et al., 1995; Hägglund et al., 1999; Curry et al., 2000; present study). The expression of mRNA for TIMP-3 was not affected by genistein treatment, indicating that it is regulated by factors other than TKs. This contention is supported by the finding that cultured granulosa cells treated with the progesterone receptor antagonist, mifepristone, expressed less mRNA for TIMP-3 compared with controls (Veloudis et al., 1998). Taken together, these data indicate that the expression of TIMP-3 may be influenced by progesterone rather than the activity of TKs.

The finding that TKs may be involved in the LH-stimulated increase in mRNA for collagenase 3 does not indicate whether this is a direct effect of LH on TKs, or if $\mathrm{LH}$ stimulates other factors that are responsible for activating TKs. Potential candidates for such intermediary factors are growth factors and cytokines. For example, interleukins are capable of activating TKs (D'Arcangelo et al., 2000; Tominaga et al., 2000), concentrations of interleukins increase in association with the gonadotrophin surge (Chen et al., 1995) and have been implicated as modulators of the ovulatory process (for reviews, see Brännström et al., 1993; Norman and Brännström, 1996; Tsafriri and Reich, 1999). Other factors that activate TKs, such as vascular endothelial growth factor and colony stimulating factor 1 , also increase in response to the gonadotrophin surge and may play a role in the periovulatory period (Koos, 1995; Christenson and Stouffer, 1997; Shinetugs et al., 1999).

The dose of genistein required to inhibit ovulation (Matousek et al., 1999) and the expression of mRNA for collagenase $3\left(100 \mu \mathrm{mol} \mathrm{I}^{-1}\right.$; present study) is similar to doses used in other in vitro studies, as discussed by Matousek et al. (1999). In this in vitro perfusion system, some compounds have to be present in the micromolar range to produce an effect because of the dilution due to the adsorption of added compounds to the tubing material and perfusion apparatus, as well as the fact that compounds added exogenously have to perfuse into the organ from the vasculature (Brännström et al., 1993; Matousek et al., 1999).
It has been well documented that LH uses various second messenger systems to effect cellular events (Davis et al., 1986; Morris and Richards, 1995; Herrlich et al., 1996; Flores et al., 1998). However, the targets of LH-stimulated second messenger activity are not as well known. The findings of the present study illustrate the importance of the LH-stimulated activity of TKs in the ovulatory process by indicating that they may mediate MMP expression and activity, thereby regulating the dissolution of the follicle wall and extrusion of the oocyte.

This work was supported by the Lalor Foundation (CMK) and grants to T. E. Curry (NIH:HD23195) and M. Brännström (MFR:11607).

\section{References}

Akarasereenont P, Mitchell JA, Appleton I, Thiemermann C and Vane JR (1994) Involvement of tyrosine kinase in the induction of cyclo-oxygenase and nitric oxide synthase by endotoxin in cultured cells British Journal of Pharmacology 113 1522-1528

Balbín M, Fueyo A, López JM, Díez-Itza I, Velasco G and López-Otín C (1996) Expression of collagenase-3 in the rat ovary during the ovulatory process Journal of Endocrinology 149 405-415

Bigg HF, Shi YE, Liu YE, Steffensen B and Overall CM (1997) Specific, high affinity binding of tissue inhibitor of metalloproteinases-4 (TIMP4) to the $\mathrm{COOH}$-terminal hemopexin-like domain of human gelatinase A: TIMP-4 binds progelatinase $\mathrm{A}$ and the $\mathrm{COOH}$-terminal domain in a similar manner to TIMP-2 Journal of Biological Chemistry 272 15 496-15 500

Boujrad N, Ogwuegbu SO, Garnier M, Lee C-H, Martin BM and Papadopoulos V (1995) Identification of a stimulator of steroid hormone synthesis isolated from testis Science 268 1609-1612

Brännström M, Johansson BM, Sogn J and Janson PO (1987) Characterization of an in vitro perfused rat ovary model: ovulation rate, oocyte maturation, steroidogenesis and influence of PMSG priming American Journal of Obstetrics and Gynecology 130 107-114

Brännström M, Woessner JF, Jr, Koos RD, Sear CHJ and LeMaire WJ (1988) Inhibitors of mammalian tissue collagenase and metalloproteinases suppress ovulation in the perfused rat ovary Endocrinology 122 1715-1721

Brännström M, Wang L and Norman R (1993) Ovulatory effects of interleukin $1 \beta$ on the perfused rat ovary Endocrinology 132 399-404

Butler TA, Zhu C, Mueller RA, Fuller GC, LeMaire WJ and Woessner JF, Jr (1991) Inhibition of ovulation in the perfused rat ovary by the synthetic collagenase inhibitor SC 44463 Biology of Reproduction 44 1183-1188

Byers M, Kuiper GG, Gustafsson J-A and Park-Sarge O-K (1997) Estrogen receptor- $\beta$ mRNA expression in rat ovary: down-regulation by gonadotropins Endocrinology 11 172-182

Chen HF, Ho HN, Chao KH, Lin HR, Huang SC, Lee TY and Yang YS (1995) Interleukin-1-beta (IL-1 beta) is increased in the follicular fluids of patients with premature luteinization American Journal of Reproductive Immunology 34 356-362

Chesler L, Golde DW, Bersch N and Johnson MD (1995) Metalloproteinase inhibition and erythroid potentiation are independent activities of tissue inhibitor of metalloproteinases-1 Blood 86 4506-4515

Christenson LK and Stouffer RL (1997) Follicle-stimulating hormone and luteinizing hormone/chorionic gonadotropin stimulation of vascular endothelial growth factor production by macaque granulosa cells from pre- and periovulatory follicles Journal of Clinical Endocrinology and Metabolism 82 2135-2142

Curry TE, Jr, Dean DD, Woessner JF, Jr and LeMaire WJ (1985) The extraction of a tissue collagenase associated with ovulation in the rat Biology of Reproduction 33 981-991 
Curry TE, Jr, Mann JS, Huang MH and Keeble SC (1992) Gelatinase and proteoglycanase activity during the periovulatory period in the rat Biology of Reproduction 46 256-264

Curry TE, Jr, Komar CM, Burns PD and Nothnick WB (2000) Periovulatory changes in ovarian metalloproteinases and tissue inhibitors of metalloproteinases (TIMPs) following indomethacin treatment. In Ovulation: Evolving Scientific and Clinical Concepts Ed. EY Adashi. Springer Verlag, New York

D'Arcangelo G, Tancredi V, Onofri F, D'Antuono M, Giovedi S and Benfenati F (2000) Interleukin-6 inhibits neurotransmitter release and the spread of excitation in the rat cerebral cortex European Journal of Neuroscience 12 1241-1252

Davis JS, Weakland LL, West LA and Farese RV (1986) Luteinizing hormone stimulates the formation of inositol trisphosphate and cyclic AMP in rat granulosa cells. Evidence for phospholipase $C$ generated second messengers in the action of luteinizing hormone Biochemistry Journal 238 597-604

Edwards DR, Rocheleau H, Sharma RR, Wills AJ, Cowie A, Hassell JA and Heath JK (1992) Involvement of AP1 and PEA3 binding sites in the regulation of murine tissue inhibitor of metalloproteinases-1 (TIMP-1) transcription Biochemica and Biophysica Acta 1171 41-55

Espey LL, Tanaka N, Adams RF and Okamura H (1991) Ovarian hydroxyeicosatetraenoic acids compared with prostanoids and steroids during ovulation in rats American Journal of Physiology 260 E163-E169

Fitzpatrick SL, Funkhouser JM, Sindoni DM, Stevis PE, Deecher DC, Bapat AR, Merchenthaler I and Frail DE (1999) Expression of estrogen receptor- $\beta$ protein in rodent ovary Endocrinology 140 2581-2591

Flores JA, Aguirre C, Sharma OP and Veldhuis JD (1998) Luteinizing hormone (LH) stimulates both intracellular calcium ion $\left(\left[\mathrm{Ca}^{2+}\right]_{\mathrm{i}}\right)$ mobilization and transmembrane cation influx in single ovarian (granulosa) cells: recruitment as a cellular mechanism of $\mathrm{LH}-\left[\mathrm{Ca}^{2+}\right]_{\mathrm{i}}$ dose response Endocrinology 139 3606-3612

Fukumoto M, Yajima Y, Okamura H and Midorikawa O (1981) Collagenolytic enzyme activity in human ovary: an ovulatory enzyme system Fertility and Sterility 36 746-750

Hägglund A-C, Ny A, Leonardsson G and Ny T (1999) Regulation and localization of matrix metalloproteinases and tissue inhibitors of metalloproteinases in the mouse ovary during gonadotropin-induced ovulation Endocrinology 140 4351-4358

Hayakawa T, Yamashita K, Tanzawa K, Uchijima E and Iwata K (1992) Growth-promoting activity of tissue inhibitor of metalloproteinases-1 (TIMP-1) for a wide range of cells FEBS Letters 298 29-32

Herrlich A, Kuhn B, Grosse R, Schmid A, Schultz G and Gudermann T (1996) Involvement of Gs and Gi proteins in dual coupling of the luteinizing hormone receptor to adenylyl cyclase and phospholipase C Journal of Biological Chemistry $27116764-16772$

Hirsch B, Leonhardt S, Jarry H, Reich R, Tsafriri A and Wuttke W (1993) In vivo measurement of rat ovarian collagenolytic activities Endocrinology 133 2761-2765

Hulboy DL, Rudolph LA and Matrisian LM (1997) Matrix metalloproteinases as mediators of reproductive function Molecular Human Reproduction 3 27-45

Inderdeo SD, Edwards DR, Han VKM and Khokha R (1996) Temporal and spatial expression of tissue inhibitors of metalloproteinases during the natural ovulatory cycle of the mouse Biology of Reproduction 55 498-508

Johnson MD, Kim H-RC, Chesler L, Tsao-Wu G, Bouck N and Polverini PJ (1994) Inhibition of angiogenesis by tissue inhibitor of metalloproteinase Journal of Cellular Physiology 160 194-202

Koos RD (1995) Increased expression of vascular endothelial growth/permeability factor in the rat ovary following an ovulatory gonadotropin stimulus: potential roles in follicle rupture Biology of Reproduction 52 1426-1435

Koos RD, Jaccarino FJ, Magaril RA and LeMarie WJ (1984) Perfusion of the rat ovary in vitro. Methodology, induction of ovulation, and pattern of steroidogenesis Biology of Reproduction 30 1135-1141

Kuiper GGJM, Enmark E, Pelto-Huikko M, Nilsson S and Gustafsson JA (1996) Cloning of a novel estrogen receptor expressed in rat prostate and ovary Proceedings National Academy of Sciences USA 93 5925-5930
Kuiper GGJM, Carlsson B, Grandian K, Enmark E, Haggblad J, Nilsson S and Gustafsson J-A (1997) Comparison of the ligand binding specificity and transcript tissue distribution of estrogen receptor $\alpha$ and $\beta$ Endocrinology 138 863-870

Li L, Akers K, Eisen AZ and Seltzer JL (1997) Activation of gelatinase A (72-kDa type IV collagenase) induced by monensin in normal human fibroblasts Experimental Cell Research 232 322-330

Li WQ and Zafarullah M (1998) Oncostatin M up-regulates tissue inhibitor of metalloproteinases-3 gene expression in articular chondrocytes via de novo transcription, protein synthesis, and tyrosine kinase- and mitogen-activated protein kinase-dependent mechanisms Journal of Immunology 161 5000-5007

Liu K, Olofsson JI, Wahlberh P and Ny T (1999) Distinct expression of gelatinase A [matrix metalloproteinase (MMP)-2], collagenase-3 (MMP-13), membrane type MMP 1 (MMP-14), and tissue inhibitor of MMPs type 1 mediated by physiological signals during formation and regression of the rat corpus luteum Endocrinology 140 5330-5338

Mann JS, Kindy MS, Edwards DR and Curry TE, Jr (1991) Hormonal regulation of matrix metalloproteinase inhibitors in rat granulosa cells and ovaries Endocrinology 128 1825-1832

Mann JS, Kindy MS, Hyde JF, Clark MR and Curry TE, Jr (1993) Role of protein synthesis, prostaglandins, and estrogen in rat ovarian metalloproteinase inhibitor production Biology of Reproduction $\mathbf{4 8}$ 1006-1013

Matousek M, Mikuni M, Mitsube K, Yoshida M and Brännström M (1999) Inhibition of ovulation in the in vitro perfused rat ovary by tyrosine kinase inhibitors Journal of Reproduction and Fertility 117 379-385

Matrisian LM (1990) Metalloproteinases and their inhibitors in matrix remodeling Trends in Genetics 6 121-125

Morris JK and Richards JS (1993) Hormone induction of luteinization and prostaglandin endoperoxide synthase-2 involves multiple cellular signaling pathways Endocrinology 133 770-779

Morris JK and Richards JS (1995) Luteinizing hormone induces prostaglandin endoperoxide synthase- 2 and luteinization in vitro by A-kinase and C-kinase pathways Endocrinology 136 1549-1558

Murdoch WJ, Peterson TA, Van Kirk EA, Vincent DL and Inskeep EK (1986) Interactive roles of progesterone, prostaglandins, and collagenase in the ovulatory mechanism of the ewe Biology of Reproduction 35 1187-1194

Murphy AN, Unsworth EJ and Stetler-Stevenson WG (1993) Tissue inhibitor of metalloproteinases-2 inhibits bFGF-induced human microvascular endothelial cell proliferation Journal of Cellular Physiology 157 351-358

Mutoh M, Takahashi M, Fukuda K, Matsushima-Hibiya Y, Mutoh H, Sugimura T and Wakabayashi K (2000) Suppression of cyclooxygenase-2 promoter-dependent transcriptional activity in colon cancer cells by chemopreventive agents with a resorcin-type structure Carcinogenesis 21 959-963

Nagase $\mathbf{H}$ and Woessner JF, Jr (1999) Matrix metalloproteinases Journal of Biological Chemistry 27421 491-21 494

Nemeth JA, Rafe A, Steiner M and Goolsby CL (1996) TIMP-2 growthstimulatory activity: a concentration- and cell type-specific response in the presence of insulin Experimental Cell Research 224 110-115

Norman RJ and Brännström M (1996) Cytokines in the ovary: pathophysiology and potential for pharmacological intervention Pharmacology and Therapeutics $69219-236$

Nothnick WB and Curry TE, Jr (1996) Divergent effects of interleukin-1 $\beta$ on steroidogenesis and matrix metalloproteinase inhibitor expression and activity in cultured rat granulosa cells Endocrinology 137 3784-3790

Nothnick WB, Keeble SC and Curry TE, Jr (1996) Collagenase, gelatinase, and proteoglycanase messenger ribonucleic acid expression and activity during luteal development, maintenance, and regression in the pseudopregnant rat ovary Biology of Reproduction 54 616-624

Nothnick WB, Soloway P and Curry TE, Jr (1997) Assessment of the role of tissue inhibitor of metalloproteinase-1 (TIMP-1) during the periovulatory period in female mice lacking a functional TIMP-1 gene Biology of Reproduction 56 1181-1188

Palotie A, Salo T, Vihko KK, Peltonen L and Rajaniemi H (1987) Types 
and IV collagenolytic and plasminogen activator activities in preovulatory ovarian follicles Journal of Cellular Biochemistry 34 101-112

Reich R, Tsafriri A and Mechanic GL (1985) The involvement of collagenolysis in ovulation in the rat Endocrinology 116 522-527

Reich R, Daphna-Iken D, Chun SY, Popliker M, Slager R, Adelmann-Grill BC and Tsafriri A (1991) Preovulatory changes in ovarian expression of collagenases and tissue metalloproteinase inhibitor messenger ribonucleic acid: role of eicosanoids Endocrinology 129 1869-1875

Russell DL, Salamonsen LA and Findlay JK (1995) Immunization against the $\mathrm{N}$-terminal peptide of the inhibin $\alpha 43$-subunit $(\alpha \mathrm{N})$ disrupts tissue remodeling and the increase in matrix metalloproteinase-2 during ovulation Endocrinology 136 3657-3664

Shimamoto T, Yamoto M and Nakano R (1998) The role of tyrosine kinase in gonadotropin-induced ovulation in the rat ovary European Journal of Endocrinology 138 594-600

Shinetugs B, Runesson E, Bonello NP, Brännström $M$ and Norman RJ (1999) Colony stimulating factor- 1 concentrations in the blood and follicular fluid during the human menstrual cycle and ovarian stimulation: possible role in the ovulatory process Human Reproduction 14 1302-1306

Smith GW, McCrone S, Petersen SL and Smith MF (1995) Expression of messenger ribonucleic acid encoding tissue inhibitor of metalloproteinases-2 within ovine follicles and corpora lutea Endocrinology 136 570-576

Su S, DiBattista JA, Sun Y, Li WQ and Zafarullah M (1998) Up-regulation of tissue inhibitor of metalloproteinases-3 gene expression by TGF- $\beta$ in articular chondrocytes is mediated by serine/threonine and tyrosine kinases Journal of Cellular Biochemistry 70 517-527

Takigawa M, Nishida Y, Suzuki F, Kirshi J, Yamashita K and Hayakawa T (1990) Induction of angiogenesis in chick yolk-sac membrane by polyamines and its inhibition by tissue inhibitors of metalloproteinases (TIMP-1 and TIMP-2) Biochemical and Biophysical Research Communications 171 1264-1271

Tominaga K, Arakawa T, Tsuno M, Kim S, Iwao H and Kuroki T (2000) Increased mitogen-activated protein kinase activities stimulated with interleukin-1-beta and mechanism(s) of the kinase signaling pathways in rat gastric epithelial cells Digestion 61 30-38

Tsafriri A and Reich R (1999) Molecular aspects of mammalian ovulation Experimental and Clinical Endocrinology and Diabetes 107 1-11

Veloudis G, Jr, Muse K and Curry TE, Jr (1998) Effects of Mifepristone (RU486) on tissue inhibitor of metalloproteinases mRNA in rat granulosa cells Journal of the Society for Gynecologic Investigation 6 64A

Wong WYL and Richards JS (1992) Induction of prostaglandin H synthase in rat preovulatory follicles by gonadotropin-releasing hormone Endocrinology 130 3512-3521

Yamashita K, Suzuki M, Iwata H, Koike T, Hamaguchi M, Shinagawa A, Noguchi T and Hayakawa T (1996) Tyrosine phosphorylation is crucial for growth signaling by tissue inhibitors of metalloproteinases (TIMP-1 and TIMP-2) FEBS Letters 396 103-107

Yoshimura Y, Santulli R, Atlas SJ, Fujii S and Wallach EE (1987) The effects of proteolytic enzymes on in vitro ovulation in the rabbit American Journal of Obstetrics and Gynecology $157468-475$

Zhu C and Woessner JF, Jr (1991) A tissue inhibitor of metalloproteinases and $\alpha$-macroglobulins in the ovulating rat ovary: possible regulators of collagen matrix breakdown Biology of Reproduction 45 334-342

Received 22 May 2000.

Accepted 25 August 2000. 